\title{
Refugee Protection in Australia: Policies and Practice
}

Protection des réfugiés en Australie : politiques et pratiques

Protección de refugiados en Australia: políticas y prácticas

\section{Mary Crock}

\section{(2) OpenEdition}

\section{Journals}

Electronic version

URL: https://journals.openedition.org/remi/12353

DOI: 10.4000/remi. 12353

ISSN: $1777-5418$

\section{Publisher}

Université de Poitiers

\section{Printed version}

Date of publication: 1 October 2019

Number of pages: $239-250$

ISBN: 979-10-90426-64-1

ISSN: 0765-0752

\section{Electronic reference}

Mary Crock, "Refugee Protection in Australia: Policies and Practice", Revue européenne des migrations internationales [Online], vol. 35 - $n^{\circ} 1$ et 2 | 2019, Online since 01 January 2021, connection on 14 April 2022. URL: http://journals.openedition.org/remi/12353 ; DOI: https://doi.org/10.4000/remi.12353 


\section{Chronique juridique}

\section{Refugee Protection in Australia: Policies and Practice}

\section{Mary Crock ${ }^{1}$}

\section{A Study in Contrasts}

Australia remains a "New World" country in the sense that its population base and continuing growth is built on immigration. The Australian Bureau of Statistics (ABS) reports that in the 2016 census over 28\% of Australians were born overseas. Australia is in a tiny minority of states that accepts refugees for resettlement through United Nations High Commissioner for Refugee (UNHCR) programs. Since World War II the country has accepted for resettlement almost 1 million refugees. However, the generosity of its formal admission programs contrast sharply with its treatment of asylum seekers and irregular migrants, most particularly those who arrive by boat without authorisation. In recent years, Australia's policies and practice in this area have become increasingly extreme, attracting sustained criticism in various international fora.

In Australia's case, undocumented maritime migrants have almost always presented as asylum seekers rather than as irregular migrants per se. This means that "irregular maritime arrivals" (IMAs) arrive typically in search of protection as refugees within the meaning of the 1951 UN Convention relating to the Status of Refugees and subsequent Protocol. Historically, the vast majority have been found to be persons who are actually owed protection under the Refugee Convention. ${ }^{2}$ In other words, most IMAs in Australia come in search protection rather than lifestyle improvement. This fact seems to have had little bearing on successive governments who have seen electoral advantage in the adoption of regressive and constrictive policies.

In recent years Australia has become perhaps the leading exponent amongst developed states of interdiction and offshore processing and warehousing of refugees. The policy is predicated on "breaking the business model" of people smugglers by denying refugees access to Australian territory. Refugees and asylum seekers transferred to the tiny Pacific state of Nauru and Papua New Guinea's (PNG) Manus Island have languished for years in primitive, challenging

\footnotetext{
1 Professor of Public Law, Law School, The University of Sydney, Law School Building (F10), Eastern Ave, Camperdown NSW 2006, Australia; mary.crock@sydney.edu.au

2 For example, in 1998-1999, approximately 97\% of Iraqi and 92\% of Afghan applicants, the vast majority of whom had arrived by boat, were granted refugee status.
} 
environments. ${ }^{3}$ Suffering all manner of hardships and privations, a number have succumbed to violence, suicide and preventable illnesses.

In one of his first phone calls to foreign leaders in 2017, President Trump had the following exchange with then Australian Prime Minister Malcolm Turnbull (who was trying to persuade the President to honour a refugee swap deal between the United States and Australia):

TRUMP: “Why haven't you let them out? Why have you not let them into your society?"

TURNBULL: "Okay, I will explain why. It is not because they are bad people. It is because in order to stop people smugglers, we had to deprive them of the product. So we said if you try to come to Australia by boat, even if we think you are the best person in the world, even if you are a Noble [sic] Prize winning genius, we will not let you in.

Because the problem with the people."

TRUMP: "That is a good idea. We should do that too. You are worse than I am."

Some of those caught by Australia's restrictive measures are, indeed, extraordinary people. As I was writing this piece, Australia's richest writing prize was awarded to a stateless Kurd incarcerated on Manus Island for more than five years. Behrouz Boochani's work is a lengthy prose poem that documents the experience of Australia's exiles. It was written using a mobile phone and short text messages sent to his Australian translator (Boochani, 2018).

In this piece I offer a reflection on how Australia has come to adopt asylum policies and practices that are mutually conflicting, cruel and confusing. Some elements in the Australian story suggest an alignment with Asian Pacific approaches to human rights. At the same time, the deterioration in its treatment of irregular migrants has been reflective of a more global decline in respect for the rule of international law in the face of political expediency.

The essay begins with a brief account of IMA migration flows in Australia's region to give context to the discussion. There follows an overview of the international and domestic legal frameworks and how these have been changed in response to different migration events. In the process, I explore the arguments made by Australia in defence of its punitive policies and practice. The reflection concludes with some comments on the political discourse in Australia, and on the potential for practical reform going forward.

\section{Australia and Irregular Migration Flows in the Asia Pacific}

By luck or good fortune, Australia's experience of migration has traditionally been a controlled affair. As an island continent geographically remote from major populations of people on the move, it has avoided many of the problems

3 In mid-2014 2,450 asylum seekers were detained on Nauru and Manus Island, 220 of them children. By early 2019 1,000 remained in custody, with all children removed to either Australia or the United States under an agreement brokered with out-going President Obama, honoured reluctantly by President Trump. See Bevan Shield, "All refugee Children off Nauru within days", The Sun-Herald, 3 February 2019, 1 and 12. See further, https://www.kaldorcentre.unsw.edu.au/publication/research-briefs 
associated with land borders. Against a population of just over 27 million and cross border movements exceeding 4 million, annual estimates of the number of migrants in the country without appropriate authorisation have remained remarkably constant at between 50,000 and $60,000 .{ }^{4}$ Most of these are "overstayers", individuals who have entered the country on valid temporary visas and then overstayed their allotted time. Such people may be in the country unlawfully but to a certain extent they are a known entity.

Apart from early conflicts with the nation's First peoples, Australia's experience of war has been vicarious (Reynolds, 1982; Connor, 2002). Its soldiers have largely fought abroad, or it has felt the effects of conflict through those given refuge on its shores. Ordinary Australians have not had to live in fear of bombardments or the deprivations of famine. Whether this privileged existence has produced a "empathy" deficit in Australians is an open question. In historical terms the country has certainly embraced migration, but on its own terms. The racially selective immigration policies that dominated until the early 1970 s were reflective, at least in part, of white Australians' feelings of cultural isolation, if not fear.

What is clear is that the arrival of boats carrying undocumented migrants engenders extraordinary concern in Australia. "Boat people" - a phrase coined in response to the outflow of refugees from Vietnam in the 1970s - almost invariably attract shrill media responses, reflective perhaps of a long-held phobia of invasion by sea.

Australia's experience of maritime asylum seekers has been episodic. Together with my colleague Daniel Ghezelbash, I have identified at least five "waves" of irregular boat arrivals in Australia starting with the end of the war in Vietnam. We argue that each wave has been marked by clearly identifiable "push factors" in the form of crises that have encouraged departures at particular points in time. Because arrivals have presented as asylum seekers, with specific protection claims made against their countries of origin, identifying common complaints or concerns is relatively easy. The number of IMAs in each wave also reflects the efficacy of measures taken to stem or control the exodus of people in each instance.

For example, a little more than 1,000 refugees arrived in Australia by boat from Vietnam between 1978 and 1980. Incidentally, because of Australia's alignment with the losing side in this war, all of those arriving by boat were offered protection almost immediately (Crock and Berg, 2011)..$^{5}$ This relatively small number of arrivals can be explained by the multi-lateral management plans devised by the coalition of countries involved in the war in Vietnam. These included the Orderly Departure Program (devised in conclusion with the new government in Vietnam) and the regional resettlement plan known as the Comprehensive Plan of Action (CPA) (Robinson, 2004; Helton, 1993).

4 Government reporting methods after 2016 make it very difficult to determine overstay rates because of the almost complete absence of published statistical data.

5 Note, however, that the experience of the boat arrivals was a factor leading to the establishment in Australia of the first formal mechanisms for the determination of refugee status. 
Almost ten years were to pass before the second wave of IMAs in Australia. Between November 1989 and 1991235 mostly Sino-Vietnamese asylum seekers travelled from Cambodia by boat, once again landing in the North of Australia in and around Darwin. The arrivals coincided not so much with the genocide in Cambodia but with the withdrawal of Vietnamese troops from that country, the organisation of elections and the repatriation to Cambodia of thousands of refugees from neighbouring countries. The tiny number arriving in Australia on this occasion met with a decidedly hostile reception. It is from this period on that policies in Australia to detain and deter "irregular" migrants were established and then entrenched. These events also marked the beginning of an era of extraordinary conflict between the executive government in Australia and the Courts over who should control immigration (Crock, 1993: chap. 4).

The third wave of IMAs followed immediately, reflecting first China's crushing of pro-democracy advocates and then initiatives in China and across the region to resolve the situation of exiles from Vietnam who were living in camps or in shanty towns. This period saw the rise of regional people smugglers in China and South East Asia known as "Snake Heads". For the first time IMAs in Australia presented as more of a mixed group comprising both refugees and individuals seeking economic advancement who were not found to be in need of protection under international law.

In the mid-1990s, the Asia Pacific went from being a host and source region for (local) refugees to a transit point for irregular migrants from around the globe. The shutting down of traditional migration routes throughout Europe brought about by tougher (and harmonised) policies within the European Union may have been one factor in the rise of unauthorized migration in the Asia Pacific. The network effect of migrants in Australia and Australia's engagement in conflicts in Afghanistan, Iraq and the Middle East generally may have been other influences (Beine et al., 2015). Whatever the cause, by 1999 Australia was receiving most of its IMAs from outside the Asia Pacific.

This fourth wave of IMAs coincided with the start of the second war in Iraq, increases in the persecution of Kurdish and Shia minorities by the Bathist regime of Saddam Hussein and the excoriating effect of the economic sanctions imposed by the United Nations (UN). ${ }^{6}$ Many of the IMAs from Afghanistan were ethnic Hazara who were facing persecution at the hands of the Taliban in that country (Sparrow, 2005).

In many instances, IMAs were using countries in the region - in particular Indonesia and Malaysia - as transit points. People smuggling operations had become both more extensive and global in their reach and operations. This became a major problem for Australia. Indonesia became the main staging point for boat departures and instead of heading for mainland Australia, smugglers began delivering their human cargo to Australian Indian Ocean territories such as Christmas Island and Ashmore Reef. Whereas earlier waves involved IMAs arriving in groups of thirty or less, as the 1990s wore on the smugglers became more and more commercialised and audacious. When boats began arriving carrying close to 500 IMAs, it was clear that the problem had reached crisis proportions.

6 UN Security Council Resolution 661 and 666. 
In Australia this fourth wave peaked with the interception of the MV Tampa, a Norwegian flagged cargo ship that had responded to distress calls by an Indonesian ferry, the Palapa $V$ which was sinking in the High Seas with 433 passengers and crew on board. When the Tampa attempted to deliver its "rescuees" to Australian authorities on Christmas Island, the government closed the ports and sent its military to board and secure the vessel. If these actions were not themselves dramatic enough to attract global interest, the ensuing battle in the Australian courts coincided exactly with the terrorist attacks in North America on 9 September 2011. These events marked the beginning of a suite of interdiction and deflection policies known variously as the Pacific Solution or Strategy described in Part 3. They also saw a shift towards the re-characterisation of asylum in Australia as an issue of national security. This was in spite of the fact that the "rescuees" on board the Tampa were overwhelmingly confirmed over time to be Convention refugees. That is, they were found to be persons fleeing the terrors of persecution (Marr and Wilkinson, 2003).

The fifth wave of IMAs to Australia shared many of the characteristics of the fourth wave. The short story is that initiatives taken following the Tampa Affair were successful in stopping irregular maritime migration for a period. With the change of government in 2007 , however, the smugglers resumed their trade. On this occasion push factors included ongoing strife in Iraq and Afghanistan, and the end of the civil war in Sri Lanka and (later) troubles in Myanmar. However, the identity of asylum seekers passing through the Asia Pacific region became truly global, with people seeking asylum from Sudan and Somalia as well as from the Middle East and later from Syria. The flow of IMA boats was halted with the re-introduction of interdiction and push-back operations. Since 2013, virtually all boats carrying IMAs have been returned to their ports of departure. As I explore in the following section, these actions have been one part only of a suite of measures that have placed Australia in an increasingly uncomfortable relationship with international human rights law.

\section{Legal Frameworks and Practical Gaps in the Protection of Migrants and Refugees in Australia}

Australia's legal and cultural heritage lies with England and Europe. For an antipodean colonial outpost, it is has pulled above its weight in international affairs and the creation of international humanitarian law. It was a driving force behind the creation of the Universal Declaration of Human Rights in 1948 and the so-called International Bill of Rights. ${ }^{7}$ Australia's accession to the Refugee Convention brought the instrument into force. It has since become party to most of the key international human rights conventions. ${ }^{8}$ Australia has supported the work of UNHCR and developed sophisticated mechanisms for determining refugee status in individuals seeking protection. These recognise the central tenet of the Convention that "refugees" as defined should not be returned (or

7 Which include in addition to the Universal Declaration of Human Rights, the International Covenant on Civil and Political Rights (1966), the Convention against Torture and Other Cruel, Inhuman or Degrading Treatment or Punishment (1984) and the International Covenant on Economic, Social and Cultural Rights (1966).

8 Exceptions include those relating to migrant workers. 
"refouled") to a place where they face persecution on one of the five Convention grounds. It has signed on to Protocols that allow individuals to bring complaints against it under the ICCPR, The Convention Against Torture and the Convention on the Rights of Persons with Disabilities, to cite a few examples.

What sets the country apart, however, is that Australia has never enacted a national Bill of Rights or otherwise enshrined the main tenets of its international human rights obligations into its domestic law. The Migration Act 1958 does provide for a form of complementary or subsidiary protection for persons fearing return to torture or other serious abuse of human rights but it has not otherwise formally enacted the provisions of the core conventions into domestic law. Another defining aspect of the Australian human rights story is that it is situated in a region where few countries have signed on to the international regime governing refugee protection. In the Asia Pacific no regional system exists for the recognition and protection of human rights.

In this part I will trace the changes made over time to Australian law and policy relating to refugees and migrants. Over the years, the legislative and policy response to irregular migration in general and IMAs in particular suggests increasingly dissonance with its international legal commitments.

While younger Australians see the Tampa Affair as the starting point for modern refugee law in Australia, the move towards harsh and restrictive policies really dates back to the 1980s and the decision to withdraw the welcome mat from the IMAs arriving from Cambodia at the end of that decade. Then Prime Minister Bob Hawke captured the mood of his (Labor) government when he addressed the asylum seekers with this quip: "Bob's not your uncle on this issue. We are not going to allow people just to jump that queue."

Under the Migration Act 1958 (Cth) it had always been possible to detain persons who entered the country without permission or who infringed the law and became liable for deportation. However, these laws were used sparingly and individuals rarely spent lengthy periods in detention. Moreover, the law allowed for regular oversight of the detention process. The Cambodians, however, were taken into custody in 1989 without the involvement of the judiciary. Nor were they given immediate access to legal or other advice. The government argued that because the group had not gone through an immigration clearance process they were deemed not to have entered the country such that the usual legislation did not apply. When these arguments failed in courts of law, the government decided to put physical space between the asylum seekers and their supporters. The Cambodians were moved from Melbourne to Sydney, then to Darwin. In 1991 the first remote detention facility was established at a disused mining camp at Port Hedland. These arrangements allowed the government to control closely who had access to the detainees.

A legal challenge brought on behalf of 15 of the Cambodians prompted legislative change to the Migration Act 1958 which was upheld by the High

9 Interview with Jana Wendt, 6 June 1990, cited in Frank Brennan (2003) Tampering with Asylum: A Universal Humanitarian Problem, UQP, 36. 
Court. ${ }^{10}$ The amendments mandated the detention of IMAs arriving in Australia between specified date for a period of 273 days. It is worth noting that the High Court showed no interest in arguments based on Australia's obligations not to arbitrarily detain individuals under the ICCPR. The Cambodians became the first of a long line of refugees and asylum seekers who have had complaints against Australia upheld by the United Nations Human Rights Committee. ${ }^{11}$ In recent years, Committee criticisms have been roundly ignored (Crock and Ghezelbash, 2010: note 86ff).

The bizarre and confusing treatment of the Cambodian IMAs ${ }^{12}$ set the scene for humanitarian migration policy in Australia for some time. After the crackdown on pro-democracy activists in China in 1989, Australia found itself host to nearly 40,000 young Chinese students. This time Prime Minister Bob Hawke went on national television to denounce the Chinese government, declaring that no Chinese student would be forced to go home. At a policy level, however, his government moved to grant the students who had arrived in the "regular" way (by plane) temporary protection visas. In 1993, this foray into temporary status was abandoned and virtually all of the Chinese asylum seekers were granted status under a formal amnesty program.

IMAs, however, continued to be detained pending determination of their asylum claims, in increasingly remote detention centres. In 1994, amendments to the Migration Act 1958 made detention mandatory and universal for all migrants in Australia who did not hold a visa or other authority to be in Australia. Critically, the post 1994 regime operated entirely without oversight from any judicial authority. Previous provisions were removed which had required suspected unlawful migrants to be arrested and brought before a magistrate within fourty-eight hours (and after arrest, every seven days until their status was determined). It is no coincidence that the same amending legislation also introduced dramatic changes to judicial oversight of migration decision making, with provisions that constrained the grounds on which the Federal Courts could review migration decisions. ${ }^{13}$ Because the Constitution guaranteed access to the High Court, within a few years this court had assumed a paralysing burden of judicial review applications involving migrants and refugee claimants, many of the latter being IMAs. ${ }^{14}$

By the end of the 1990s, with political and practical pressures around the treatment of IMAs coming to a head, the then conservative Coalition government re-introduced temporary protection visas. The government was languishing in

10 Chu Kheng Lim v. Minister for Immigration and Ethnic Affairs (1992) 172 CLR I. 11 A v Australia Communication No 560/1993, UN Doc CCPR/C/59/D/560/1993 (30 April 1997).

12 The Cambodians would eventually spend some four years in detention before arrangements were made to first return them to Cambodia for a period of twelve months, after which they were all sponsored for re-entry into Australia. Within the context of South East Asian politics, it should be acknowledged that the situation in Cambodia was extremely complex. The asylum seekers arriving in Australia were among many who had fled the country to seek protection in the region.

13 See Migration Act 1958, s 474 ff.

14 Ibid. 
the polls and seemed almost certain to be defeated in the elections due in October 2001. The arrival of the Tampa operated as a political circuit breaker. Then Prime Minister John Howard gained considerable political capital by adopting strong-man tactics, denying entry to the asylum seekers on board the rescue vessel.

It is worth noting that Howard was in Washington DC at the time of the 9/11 terrorist attacks. His ensuing decision to conflate border control with national security therefore had a personal aspect to it. The stand-off with the MV Tampa was resolved through the intervention of UNHCR and arrangements with the International Organisation for Migration (IOM), Nauru, Papua New Guinea (PNG), New Zealand and Norway. The Tampa asylum seekers, along with others intercepted at sea around the same period, were transferred to Nauru or PNG's Manus Island, with some families and unaccompanied children accepted for immediate resettlement in New Zealand and Norway. At the same time, "Operation Relex" was instituted to intercept asylum seeker boats at sea, where possible returning them to Indonesia. All of these measures were hugely controversial at the time, attracting vociferous protest in some quarters but enjoying equal and opposite support from popularist media commentators - and the silent majority (Marr and Wilkinson, 2003). Legal challenges failed in the superior courts (Crock and Berg, 2011: chap. 4).

In the wake of the Tampa Affair the conservative Coalition prevailed at the Federal election in October 2001. The government also won bi-partisan support for a suite of legislative and policy measures that placed increasing distance between Australia's domestic laws and its international legal obligations. These included legislation to legitimate retrospectively all actions taken in the course of the Tampa Affair and the establishment of Operation Relex, as well as laws "excising" territories outside mainland Australia from the "migration zone". The interdiction and "offshore processing" scheme adopted by Australia was extraordinary but not unique in terms of state practice. The system was modelled largely on similar practices adopted by the United States in the 1990s to deny asylum seekers from Haiti access to US territory, with a holding and processing centre established at Guantanamo Bay (Ghezelbash, 2018). The parallels between Australian and US practice since that time have only increased over time. The aim in both countries has been to create "exceptional" spaces in the law where the Rule of Law would not apply. In both instances the attempts have enjoyed some but not complete success.

In 2004 a series of legal challenges were made to the mandatory detention laws in the High Court. The Court affirmed the power in government to detain non-citizens whatever their age, the length of their detention and whatever the conditions in which they were kept. However, the judiciary did push back against legislative attempts to restrict access to judicial oversight either directly or indirectly through artificial constructions of territory and decision making structures (Crock and Berg, 2011). In 2012, a (Labor) government also suffered a significant defeat when a challenge was made to a regional arrangement to transfer IMA asylum seekers to Malaysia in exchange for refugees processed in that country by UNHCR (Kneebone and Pickring, 2007). 
In more recent years the general trend in the courts to support government policy relating to asylum seekers and refugees has strengthened (Gleeson, 2016). Regrettably, the overall effect has been that domestic legal challenges have become less and less relevant. The battle lines in the human rights law have been drawn increasingly between the politicians and between the political classes and civil society.

In between, there can be little doubt about the human impact of Australia's policies. Wherever Australia has held asylum seekers over time and in remote locations, human rights abuses have followed. Detainees have committed suicide, engaged in self-harm and in harmful actions towards each other. They have suffered abuse at the hands of their guards. Women and children have been sexually and physically abused; children have developed resignation syndrome, some becoming unresponsive and even catatonic. This has been the case both in the detention centres established across Australia and on the Australian territory of Christmas Island in the Indian Ocean. It has been equally true of the centres established abroad which have been run at Australia's behest under the ostensible authority of Nauru and PNG (Gleeson, 2016).

\section{The Politics of Refugee Protection in Australia}

In some instances, victory for the government in the courts has provided political space for insiders to push for more compassionate treatment. For example, in 2005, pressure from within the government lead to the release of many long term detainees who were (eventually) granted permanent resident visas. ${ }^{15}$ The Migration Act was amended to provide that the incarceration of children should be a measure of "last resort"; Manus Island and the camps on Nauru were closed. The last of the Tampa era refugees had been granted residence in Australia by the time Labor came to power in 2007. ${ }^{16}$

In my view, the most damaging aspect of this history, however, is the extent to which the containment of IMAs became a vehicle for political point scoring. In 2001, the strong arm tactics against the Tampa helped build the electoral fortunes of a government struggling in the polls. When the conservative Coalition lost power in 2007 and boats carrying IMAs began again, it found electoral capital in urging a return to policies and practices known to be contrary to basic tenets of humanitarian law. In the face of a concerted campaign that it had gone "soft" on border control the Labor government executed a series of backflips. It re-introduced de facto temporary protection in the form of suspension in the processing of refugee claims by asylum seekers from Sri Lanka and Afghanistan. A rather ham-fisted attempt was made to emulate the Coalition's push-back policy with the return to Indonesia a group of asylum seekers interdicted en route to Australia.

$15 \mathrm{Mr}$ Al-Kateb was granted a subclass 695 "Return Pending visa" which allowed him to leave detention but with no right to work or to medical or other benefits. He was granted permanent residence in December 2006.

16 ABC News (2004) Last Detainee Leaves Manus Island, May 30, [online]. URL: http:// www.abc.net.au/news/stories/2004/05/30/1119172.htm 
The irony of the situation is that the so called "softening" of asylum policy after the election of the Labor government in 2007 was more about perceptions than substantive change to law and policy. The changes made by Labor were neither radical, nor did they alter the mainstays of the structures set up under the Coalition. At the same time, they were made in the context of a period of increasing internal political dysfunction. By the time the government changed again in 2013, Labor had changed its leadership twice in the space of three years (Gleeson Kaldocentre). The failure to manage the influx of IMAs arguably played into this chaos.

After 2013, the harshness of Australia's treatment of IMAs increased exponentially as the Conservative government doubled down on its electoral promise that it would "Stop the Boats". While it was Labor Prime Minister Kevin Rudd who decreed that no IMA should ever be allowed to resettle in Australia, it was successor, conservative, Prime Ministers who prosecuted this policy, albeit unevenly. As Nauru and Manus Island had very small capacities not all IMAs could be transferred. Who was chosen for exile became highly arbitrary, which in itself provided scope for cruelty in the form of arbitrary separation of family groups.

Two signature changes were made to government policy and practice in and after 2013. The first was the adoption of turn-back and return policies. In the early days this included using high visibility orange inflatable boats on to which IMAs rescued at sea were loaded and then returned to Indonesia (Kaldorcentre). The second and equally important initiative was that the Conservative government "shut down the shipping news", taking complete control over what information was made public about "on-water operations", who was arriving and what was happening to IMAs. The effect was to create both the appearance of and the framework for control. And it worked.

The simple point to make is that international human rights and the Rule of Law ceased to be so much part of the discourse in Australia. To the extent that politicians were prepared to acknowledge the harm being done to detainees and to the IMAs transferred offshore, the almost universal justification became the assertion that the measures were necessary to save deaths at sea. These arguments persisted even as a succession of IMAs transferred to Nauru and Manus Island died or suffered injuries of sufficient gravity to require medical evacuation to Australia.

Interestingly, the Minister charged with developing and implementing the turn back and offshore processing strategies came from a background in commercial advertising. He was succeeded by a more traditional "strong-man" personality who actively promoted bureaucrats who would weed out the "care bears". Minister Dutton oversaw a major re-structuring of government functions with the amalgamation of immigration, customs and national security into the one super-department of Home Security. What had been the Department of Immigration and Citizenship became the Department of Immigration and Border Protection. It is a measure of the political power accrued in this space that when the Conservatives succumbed to their own internecine dysfunction in 2018, the two contenders (Peter Dutton and Scott Morrison) who emerged for the position of Prime Minster were both past or present Ministers with responsibility for immigration. 
Whether its geopolitical location has contributed to Australia's pursuit of laws and policies that are plainly at odds with its obligations under human rights law is an open question. What is clear is that not all of the policies claimed as effective in "Stopping the Boats" are sustainable. The maintenance of holding and processing centres on Nauru and Manus Island has been hugely expensive in terms of fiscal and human cost. Offshore processing is reputed to cost Australia in excess of three billion Australian dollars a year, while its policies had been linked to a disturbing number of at least twelve deaths by 2019 . While the swap agreement with the United States has seen some transferees released to a new life, resolution has been painfully slow and incomplete. With the prospect of a change of government in the 2019 Federal election, the resolution of the situation of the thousands of IMAs affected by Australia's restrictive policies (both offshore and in the country) should have been a matter of pressing concern. The fact that the issue did not feature in the campaign underscores the political sensitivity of the issue. In fact, the conservatives were re-elected with a slim majority. For detainees in Australia and for those warehoused offshore, the cruel uncertainty has continued even as refugees have slowly been resettled in the US or transferred to Australia for medical treatment.

\section{References}

Alnasrawi Abbass (2000) Iraq: Economic Embargo and Predatory Rule, in E. Wayne Nafziger, Frances Stewart and Raimo Väyrynen Eds., Hunger, and Displacement: The Origins of Humanitarian Emergencies, Volume 2, Oxford, Oxford University Press, 516 p.

Beine Michel, Docquier Frédéric and Ozden Caglar (2015) Dissecting Network Externalities in International Migration, Journal of Demographic Economics, 4, pp. 379-408.

Boochani Behrouz (2018) No Friend but the Mountains: Writing from Manus Prison, Sydney, Picador, $374 \mathrm{p}$.

Connor John (2002) The Australian frontier wars, 1788-1838, Sydney, UNSW Press, $175 \mathrm{p}$.

Courtland Robinson W. (2004) The Comprehensive Plan of Action for Indochinese Refugees, 1989-1997: Sharing the Burden and Passing the Buck, Journal of Refugees Studies, 17 (3), pp. 319-333.

Crock Mary (1993) A legal perspective on the evolution of mandatory detention, in Mary Crock Ed., Protection or Punishment: The Detention of Asylum Seekers in Australia, Sydney, Federation Press, pp. 25-40.

Crock Mary and Berg Laurie (2011) Immigration, Forced Migration and Refugee: Law, Policy and Practice in Australia, Sydney, Federation Press, 698 p.

Crock Mary and Ghezelbash Daniel (2010) Do Loose Lips Bring Ships? The Role of Policy, Politics and Human Rights in Managing Unauthorised Boat Arrivals, Griffith Law Review, 19 (2), pp. 238-287

Ghezelbash Daniel (2018) Refuge Lost: Asylum Law in an Interdependent World, Cambridge, Cambridge University Press, 225 p. 
Gleeson Madeline (2016) Offshore: Behind the Wire on Manus and Nauru, Sydney, New South Publishing, 510 p.

Helton Arthur C. (1993) Refugee Determination under the Comprehensive Plan of Action: Overview and Assessment, International Journal of Refugee Law, 5 (4), pp. 544-558.

Kneebone Susan and Pickering Sharon (2007) Australia, Indonesia and the Pacific Plan, in Susan Kneebone and Felicity Rawlings-Sanaei Eds., New Regionalism and Asylum Seekers: Challenges Ahead, New York, Berghahn Books, pp. 167-175.

Marr David and Wilkinson Marian (2003) Dark Victory, Sydney, Allen \& Unwin, $350 \mathrm{p}$.

Reynolds Henry (1982) The Other Side of the Frontier: Aboriginal Resistance to the European Invasion of Australia Ringwood, Sydney, Penguin Books Australia, $255 \mathrm{p}$.

Robinson Courland W. (2004) The Comprehensive Plan of Action for Indochinese Refugees, 1989-1997: Sharing the Burden and Passing the Buck, Journal of Refugee Studies, 17 (3), pp. 319-333.

Sparrow Phil (2005) From under a Leaky Roof: Afghan Refugees in Australia, Sydney, Fremantle Arts Centre Press, 160 p. 